\title{
MITIGATION OF SAFETY VULNERABILITY OF PEOPLE AND PROPERTY FROM THE EFFECTS OF EXPLOSIONS OF EXPLOSIVE MATERIALS IN THE SERBIAN ARMY
}

\author{
Dejan S. Stojanovića ${ }^{a}$ Petar Lj. Stojilkovićb \\ ${ }^{a}$ Serbian Armed Forces, $4^{\text {th }}$ brigade of Land Forces, \\ Vranje, Republic of Serbia, \\ e-mail: dejans44@yahoo.com, \\ ORCID iD: (itttp://orcid.org/0000-0001-6220-5990 \\ ${ }^{\mathrm{b}}$ Institute for safety and health at workand fire protection VIP Centar doo, \\ Leskovac, Republic of Serbia, \\ e-mail: vip.agencija@yahoo.com \\ ORCID iD: idttp://orcid.org/0000-0001-8290-924X
}

DOI: 10.5937/vojtehg64-8399

FIELD: environmental protection and crisis management

ARTICLE TYPE: review paper

ARTICLE LANGUAGE: English

\section{Summary:}

The aim of the research is to provide proactive mitigation of safety risk to people and property of the effects of explosions of explosive materials in the Serbian Army based on a large number of relevant collected data. Achieving these research goals requires the use of appropriate methods and techniques for understanding and studying the existing theoretical and practical solutions as well as proposing new solutions in the area of interest. The research includes possibilities to mitigate risk to people and property from the effects of explosive material explosions. These possibilities aim at reducing danger, risk and threat to the population, their property and the environment, as well as at mitigating the consequences of possible emergencies. The following methods have also been discussed: avoidance, retention, reduction, division, transfer and reduction of hazards, risks and threats, where for each method a detailed theoretical explanation is provided with appropriate examples of good practice. The formulated hypothesis is also being proven, with the aim to - with a scientific objectivity towards one's own research results accept or reject the proposed methods.

Key words: threat, danger, army, property, explosive. 


\section{Introduction}

One of the properties of explosive materials is that in a short period of time, under certain external influences, through chemical decomposition, they create a lot of pressure and release a lot of energy in the form of heat or gases capable of performing mechanical work over the environment and thus achieve the effect of explosion ${ }^{1}$. This chemical process partially or completely damages or destroys the environment in a closer or farther area, causing casualties and damage to material goods. Therefore, explosive materials are considered to be one of potential causes of safety vulnerability of people and property from the effects of explosions of explosive materials. Above all, since it is known that the majority of the Serbian Army personnel are exposed to some form of danger, risks and threats from explosion effects of explosive materials that can occur in different forms and affect the functioning of the whole system, opportunities for mitigating these phenomena become significant.

Since the process of mitigation of safety vulnerability of people and property from explosive material explosions is complicated, complex and interdisciplinary, and since it is not fully defined in relevant literature, this paper tends to comprehensively and systematically deal with all the relevant issues (with appropriate examples from practice) which affect the modern process of mitigation of danger, risks and threats. By analyzing the views of several authors ${ }^{2}$ who were engaged in risk management and experience guidance ${ }^{3}$, we have searched for a solution closest to the subject area in order to ensure improvement in the field of increasing the safety of people and property which is important for mitigation of explosion effects of explosive materials in the Serbian Army.

\section{Mitigation of safety vulnerability of people from the effects of explosions of explosive materials}

Mitigation of safety vulnerability of people and property from the effects of explosions of explosive materials is a mental process built on early detection and acknowledgement of danger, risk and threat from

\footnotetext{
${ }^{1}$ Explosives (lat. Exploder - decay) are gaseous, liquid or solid chemical compounds or mixtures which decompose under the influence of specific activation energy with the release of large amounts of heat and heated gases the expansion of which leads to an abrupt increase of pressure in a very short time interval. Explosives are materials used for demolition, divided into initial (primary) and brisant (secondary) ones (Radovanović, 2011).

2 The emphasis in this paper is given in (Mijalkovski, Đorđević, 2010) and (Keković, Nikolić, 2006).

3 Acquired during the period of temporary work by Dejan Stojanovic as a protection of resources officer in the $4^{\text {th }}$ brigade of Land Forces, Vranje.
} 
explosive material explosions based on the assessment of locations in which explosive materials can be found. In the decision-making process, before an actual explosion of explosive materials has occured, personnel in charge ${ }^{4}$ tend to determine a character of real or potential safety vulnerability of people and property from explosive material explosions in order to make proper decisions and thus provide optimal protection to all the members of the Serbian Army. This is why each assessment needs to be objective since wrong or unrealistic assessments can lead to wrong decisions and pose danger, risk and threat to all the subjects in the system.

The research of the safety vulnerability of people and property from explosive material explosions in the Serbian Army has led to the assessment ${ }^{5}$ that danger, risks and threats from the effects of explosive material explosions, in a certain period of time and under certain circumstances, can have an effect on the entire safety situation in the Serbian Army. This is why the personnel from commands, units and institutions have to decide on how to react in critical situations. They make their decisions in accordance with the existing structure and jurisdiction of the management and the executive department of the system of defence, defined by the Constitution of the Republic of Serbia, the Law on Defence and the Law on the Army of Serbia. The decisions are made in order to reduce the level of danger, risk and threat of explosive material explosions to the minimum, or to a moderate level. Methods for mitigation of safety vulnerability of people and property from the effects of explosive material explosions are recommended for the purpose of reducing the possibility of explosions with a disastrous outcome.

The proposed methods to mitigate safety vulnerability of people and property from the effects of explosions of explosive materials are: avoidance, retention, impairment, division, transfer and reduction of hazards, risks and threats (Figure 1).

\footnotetext{
${ }^{4}$ Persons who are, in accordance with laws and regulations, authorized to govern or command military units (institutions), commands, units or institutions i. e. their personnel. Other persons in units (institutions) are subordinates. Superiors are those with higher ranks. If they are of the same rank or without ranks, a superior is the one on a higher level of duty, and if they are on the same duty level, the superior one is the one who has been promoted first (Pravilo službe Vojske Srbije / Service Regulations of the Serbian Armed Forces, 2008, p.10).

${ }^{5}$ The assessment of the situation of vulnerability of people and property from the effects of explosions of explosive materials in the Serbian Army, made in earlier assessment stages, has shown that the level of hazards, risks and threats from the occurrence of the effects of large explosions of explosive materials is high and as such is not acceptable for the Serbian Army (Stojanović, 2015, p.159).
} 


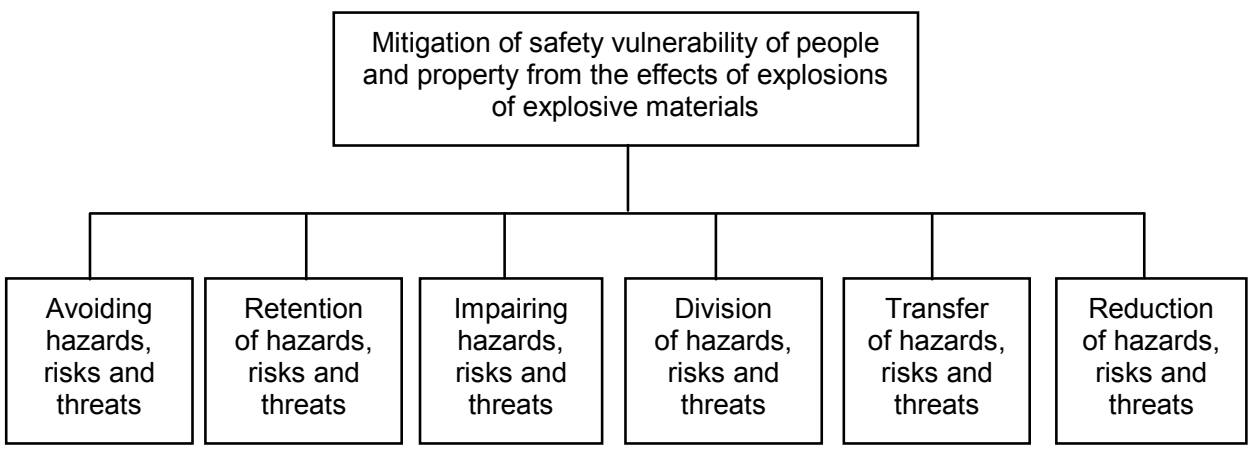

Figure 1 - Methods for mitigating safety vulnerability of people and property from the effects of explosive material explosions

Puc. 1 - Методы по предотвращению и смягчению последствий взрыва взрывчатых средств

Slika 1 - Metode za ublažavanje bezbednosne ugroženosti ljudi i imovine od efekata eksplozije eksplozivnih sredstava

In this case, mitigationof safety vulnerabilityof people and property from the effects of explosionsof explosive materials includes a theoretical treatment of certain methods applied in practice in a combination with several others (when they depend on each other) or individually when referring to a specific event. Which of the proposed methods will be applied in a particular period and to what extent will be a decision of the commander or other persons responsible for mitigating safety vulnerability of people and property from the effects of explosive material explosions at a critical moment. It is necessary to provide a continuous adjustment of planned methods to new conditions in order to mitigate potential hazards, risks and threats of unwanted events as much as possible and to prevent possible human casualties due to explosive material explosions.

\section{Avoiding hazards, risks and threats}

It is possible to put the mitigation of hazards, risks and threats by avoidance into practice only by avoiding an activity for which it is estimated that can lead to the explosion of explosive materials. This assessment is made by commanders of particular units or by the Ministry of Defence who observe to what extent the safety measures have been violated and can lead to potential dangers, risks and threats from explosions of explosive materials. After that, the decision is made to avoid certain activities in order to overcome the situation. It has to be kept in mind that avoiding the implementation of one activity may lead to a creation of other hazards, risks and threats from the occurrence of the effects of explosions of explosive materials. Therefore, the basic rule is 
that it is best to put into practice an activity the damage of which is estimated to be of lower intensity, and avoid danger, risk and threat likely to cause damage of higher intensity. In some instances, this is the only possible practical alternative.

Example: There is a real danger, risk and threat from the effects of explosions on the Combined-Arms training ground "Pasuljanske livade" due to unexploded ordnance that can be foundon the training ground around the Krcora hill, where targets are placed (while performing tactical exercises with live firing). The most acceptable method that mitigates any danger, risk or threat of explosion effects of explosive devices at the test site is to put a target in a safer place to avoid any form of danger, risks and threats of having effects of explosions of explosive materials.

It should also be noted that the Serbian Army completely alleviates dangers, risks and threats by avoiding activities assumed to bea cause of unwanted events. In some cases this can be effective, but not practical for the functioning of the Serbian Army which represents defence system armed forces and the armed opposition to military and non-military ${ }^{6}$ forms of en dangering the state security (Keković, Nikolić, 2006, p.421). Therefore, it is necessary to avoid only those forms of danger, risks and threats with assessed high probability of unwanted events occurrence during the effects of explosion.

\section{Retention of hazards risks and threats}

While working with explosive devices, individuals as well as entire teams are faced daily with virtually unlimited hazards, risks and threats mitigated by subconscious or conscious retention. If individuals or teams during the implementation of tasks in such work environment are not aware that they are exposed to hazards, risks and threats from the appearance of the effects of explosive material explosions, then in such situations they subconsciously react to danger, risk or threat, since the brain creates a defense mechanism that warns them against risk at a certain point and sends signals that they should be careful to avoid any unintended consequences. In such situations, danger, risk and threat are subconsciously retained, which in certain jobs (such as jobs with special working conditions ${ }^{7}$ or, jobs that cannot be avoided due to their

\footnotetext{
${ }^{6}$ The strategic documents of potential challenges, risks and threats to national security are defined and may be of a military (aggression, armed conflicts, armed rebellion escalation of terrorism and other conflicts with the use of weapons) and anon-military nature (national and religious extremism, organized crime, corruption, natural disasters, industrial and other accidents and epidemics).

7 Jobs with special working conditions include jobs with particularly difficult tasks, dangerous to life and health, harmful jobs, or jobs in which professional military personnel are exposed to specific efforts and increased risks.
} 
importance) is not enough, so each activity needs to be consciously considered during work. In such a case, individuals or teamsaware of hazards, risks and threats do not want to accept them to the extent required from them in order to put the entire activity into practice, so they consciously postpone the activity when they estimate that their lives are in danger from the explosion of explosive materials, until the change of a decision. This is how a safety situation is created for the continuation of planned activities and the safety of people and property is increased.

Example: An order was issued by the superior command thattargets should be placedon Krcor hill. When issuing orders, a superior is required to consider whether they can be carried out or not (Pravilo službe Vojske Srbije / Service Regulations of the Serbian Armed Forces, 2008, p.20). Targets are placed at designated places, and attention is subconsciously paid to movement areas and the place where targets are set. But if prudent thinking, perception and reasoning prevail, then it is easy to realize that the area in which the target is placed is very risky to stay in, because of unexploded projectiles which can be activated due to negligence and cause unwanted consequences. In such situations, an individual deliberately slows down the implementation of the task and points to the problem in order to change the decision or possibly correct it. In a situation where the decision is not changed, the task is subconsciously completed or consciously rejected because it threatens the safety measures. After wards, the explanation for such behavior and task rejection is given to the superior command.

As a rule, hazards, risks and threats mitigatedby conscious retention result in unwanted events with relatively small human and material losses, and as such are favorable for the Serbian Army, while dangers, risks and threats mitigated by subconscious retention result in greater human and material losses and as such are not favorable for the Serbian Army. It is certain, however, that retention of hazards, risks and threats is not desirable in the case of severe hazards, risks and threats, and is acceptable only in a situation where the probability of occurrence of hazards, risks and threats is small (Karović, Komazec, 2010, p.237).

\section{Impairment of hazards, risks and threats}

Impairment of hazards, risks and threats from the occurrence of the effects of explosive material explosions can be put into practice only if the activity in the workplace is interrupted when the human body experiences too much physical and psychological stress. Practice has shown that most of damage caused by the explosion of explosive materials in the Serbian Army occurred due to the weakness of the human organism during increased physical and mental strain. Creating appropriate working 
conditions and organizing living and working as intended, in line with the tasks and conditions of units and institutions of the Serbian Army, reduces the load on the human body. The load during working processes and the objective capabilities of the human organism are often in great discord which results in fatigue, tiredness, exhaustion, moodiness, tension and the lack of desire to work. Therefore, in areas where there is increased danger, risk and threat of the occurrence of the effects of explosionsof explosive materials, the following measures should be taken: making more frequent breaks, reducing work intensity and improving the functioning of the system by adapting the work process to real conditions (this can be achieved by adjusting the maximum speed of work to the workflow, adjusting the working temperature to the working conditions, reducing the noise to the permitted level, etc.). The Serbian Army has very responsible and complex tasks: to create a system functioning in the prescribed working conditions as well as to enable and motivate individuals to work in certain situations based on defined working conditions, thus preventing human and material losses.

In order to reduce threats, risks and hazards from the explosions of explosive materials, it is important for the commander or other persons responsible for making decisions in critical situations, to make decisions on the working process until the moment when the body fatigue appears due to in adequate working conditions. This is the way to reduce the number of accidents (frequency) or the amount of danger (intensity), because it is virtually impossible to fully prevent all losses.

Example: One member of the military personnel did not make a right decision while clearing the remaining cluster bombs on mountain Kopaonik. On that day when he became an invalid, he had already destroyed 106 cluster bombs. There was one more, 107th, a fatal one which had a contactless, seismically activating fuze. If he had stopped working when experiencing fatigue due to in adequate working conditions, he would probably have both hands now. This is just one of many events having occurred in recent years.

Therefore, in order to reduce hazards, risks and threats from explosions of explosive materials, it is important to recognize moments of too much physical and mental pressure and to stop work in order to reduce consequences from unwanted events, i.e. minimise material and economic losses.

\section{Division of hazards, risks and threats}

Mitigation of hazards, risks and threats by division is conducted by dividing hazards, risks and threats from explosion of exlosive materials into several partial, less dangerous hazards, risks and threats which are individually much easier to control. This is how unwanted events are 
restricted in intensity and area so that human losses and material damage are kept to the minimum.

Example: Instead of storing explosive materials in one warehouse (storage area) of larger capacity, it is better to store them in two warehouses of smaller capacity placed at a sufficient distance from one another ${ }^{8}$ in order to prevent the effects of an adverse event which may occur in one warehouse to affect what is stored in the other one.

The division is also carried out during some operational activities. It is essential that a Serbian Army unit planning to work with explosive materials consider the question of danger, risks and threats from the effects of an explosion and divide the activity into smaller partial operations.

Example: In the Department of Operations of Unexploded Ordnance, the biggest problem for deminers is to assess the fuze condition, because they cannot see inside the fuze mechanism and the phase its arming is in. Aware of the importance and the responsibility for the work they do (in their case there is no second attempt), they are forced to perform the job slowly, with the division of their work into several partial operations. Therefore, the demining of unexploded explosive devices cannot be simultaneously operated by two or more men, but only by one at a time, and to a certain moment, after which that person is replaced. Another member of the team waiting for his turn to continue demining explosive devices assists the deminer, while the other team members are in the shelter. They use IT support from the headquarters to search the database for missiles and fuzes based on the information they get from the field. Deminers must be fully concentrated since any mistake could be fatal.

In the process of decision making, breaking perceived dangers, risks and threats of the effects of explosive devices down into several partial hazards, risks and threats, or dividing them into several partial activities, is sometimes the only solution to avoid unwanted events.

\section{Transfer of hazards, risks and threats}

Mitigation of hazards, risks and threats from exlosions of explosive materials by transfer is obtained when hazards, risks and threats are transferred from one person to another person or to an organization. Hazards, risks and threats from explosions in the working environment are, therefore, transferred from one person, who is not certain of his or

${ }^{8}$ Inter-warehouse distances are distances between adjacent warehousesin which explosive materials are stored. The minimum permitted separation distances between the warehouses are those that effectively protect against transmission of the explosion from one warehouse to the adjacent one, where the presence of staff is not taken into account (Upustvo za rad skladišta ubojnih sredstava / Manual for ordnance warehouses, 2002, p.63). 
her ability to accept hazards, risks and threats to the requested extent,to another person or organization ready to take responsibility in such a situation. Thisother person ororganization differs from the first one in the level of decisiveness, readiness and dedication. The one to whom the hazards, risks and threats of the explosion are transferred to consiously accepts responsibility that the one who they were transferred from wants to avoid, and therefore is trying to mitigate or fully eliminate the possibility of their occurrence in order to increase the safety of peple and property. The person accepting this needs to be more experienced and skilled in the field of hazards, risks and threats and ready to take full responsibility.

Example: Artillery firing from a self-propelled $122 \mathrm{~mm}$ howitzer is taking place on the military training ground "Pasuljanske livade". A battery commander is in charge of firing. If the first projectile is unobserved firing, then the division commander as the most responsible and the most experienced officer, finds that a blunder has occurred and continues firing until an observed hit occurs. The commander of the division thus takes responsibility for the action and prevents occurrence of unwanted situations.

Hazards, risk and threats from the effects of explosions of explosive materials are transferred to an organization by making an agreement or a contract on taking responsibility. One of the parties agrees to take responsibility in case of material damage or losses of human lives, which is sometimes inevitable. These agreements or contracts are concluded before the damage occurs (and must be realized in the stipulated period of time). This ensures that unexpected expenses or damage which occurred while performing the contracted activity, are reimbursed by the other party. In such situations, hazards, risks and threats are mitigated by transferring financial consequences of any explosive material explosions from the Serbian Army to some other organization. Organizations which accept these agreements first need to assess the frequency and intensity of possible risks they are taking, based on previous experience and accept all the conditions and actions in order the avoid the risk that has been passed on to them (Vujović, 2009).

Example: The risk of explosions during demining of mines and cluster bombs left from NATO raids on Serbia was transferred from the engineering units of the Serbian Army to specialized companies and other organizations registered for these activities, with appropriate technical equippment and trained staff. Therefore, with a purpose of harmonizing activities related to humanitarian demining, the Mine Action Centre has been established in Serbia. The Mine Action Centre was founded in 2002, initially as a federal body within the Ministry of Foreign Affairs, and in 2003, by a respective government decision, it became a body at the republic level, first as a government department, and later as a separate organization. It investigates locations suspected of being 
contaminated by cluster munitions, landmines and other unexploded ordnance, develops projects for demining, submits them to donors or international foundations to ensure donations for their implementation, performs quality control of demining, performs international cooperation, ensures the implementation of international standards and the implementation of international agreements and treaties (Centar za razminiranje / Mine Action Centre, http://www.czrs.gov.rs/lat/o-nama.php).

At workplaces where hazards, risks and threats of the effects of explosive material explosions become increasingly common, many persons resort to transferring the decision-making process to another person or they resort to signing fixed-contract agreements with other organizations ready to take the risk for a certain amount of financial compensation.

\section{Reduction of hazards, risks and threats}

The most efficient way of mitigating hazards, risk and threats by reduction is to implement preventive actions to reduce the frequency or intensity of consequences in order to affect any possible occurrence of the effects of explosive material explosions in the working environment (Keković, Nikolić, 2006, p.421). Prevention represents a series of activites directed to reduce the likelihood of the adverse event occurrence, i.e. to reduce a possibility of its occurrence, and reduce its consequences in case it does occur after all. These are the main characteristics and tasks of prevention and the only way to purposefully conduct prevention and ensure safety of people and property. Prevention of hazards, risks and threats tends to reduce material losses and human casualties that the Serbian Army has been facing lately. This depends especially on hazards, risks and threats in work environments where explosives ${ }^{9}$ are involved. It is the Serbian Army's interest to widely implement activities that lead to the increse of general safety and quality of life of its members and to reduce expences for remediation of damage. Some events occur despite the greatest efforts of the Serbian Army to predict future scenarios of occurrence of unwanted events. This is why it is necessary to undertake certain steps to reduce their intensity to the minimum. Preventive actions

\footnotetext{
${ }^{9}$ The timeline of unfortunate events in the industry for the manufacturing of explosive devices in recent years was as follows: May 29th 2006, an explosion in "Prva Iskra" in Baric claimed three lives while three workers were injured; on September 4th 2009, in four powerful explosions in the gunpowder department of "Prvi Partizan" Factory in Uzice, seven workers were killed and thirteen were injured; on May 10th 2010, in the detonation in the "Krusik" Factory in Valjevo two workers were slightly injured; on December 27th 2010, a series of explosions in the "Sloboda" Factory in Cacak caused significant material damage; on September 21st 2011, June 25th 2012, and September 30th 2015, workers were injured in explosions in the "Milan Blagojevic" Factory in Lucani (Stojanović, 2015, p.153).
} 
are implemented in order to reduce the consequences. A significant preventive action would be to issue a set of provisions which regulate protection from explosions at the Ministry of Defenceand in the Serbian Army, which would successfully determine the rules of behavior in the working environment, and also avoid the slightest possibility of the occurrence of the effects of explosive materials explosion.

Accepting and implementing international, primarily European, as well as the national rules and regulations in the field of protection from the effects of explosive material explosions, will provide well-regulated prevention and a possibility for quick and appropriate interventions. The activities will also be directed towards issuing technical rules and regulations on the methods of mitigating damageand providing functional integrity of all services. Cooperation, coordination and availability of information will increase the speed and efficiency of reacting to the occurrence of the effects of explosive material explosions in the Serbian Army.

Example: A few years ago, explosions of explosive materials with the disastrous outcome occurred in the industry for manufacturing explosives. Those in charge then improved the safety program which includes the implementation of rules on functioning of the industrial system for manufacturing and trade of explosive materials and thus prevented human casualties and material losses. The Regulations on Fire Protection at the Ministry of Defence and in the Serbian Army prescribe that in the premises where explosive materials are stored certain preventive rules and regulations should be apllied in order to prevent any kind of safety vulnerability of people and property in the working environment (Službeni vojni list/Official Military Gazette, 2015). This contributed to avoidance of human casualties, reduction ofthe amount of damage, and reduction of intensity of the damage that had already occurred.

In places where explosive materials can be found, appropriate methods of conduct had been prescribed, which resulted in avoiding unwanted events with the disastrous outcome, while material damage was reduced compared to previous years.

\section{Results of the research and the discussion}

In accordance with the subject of research and available information, this paper sets a hypothesis:

- Certain methods for the mitigation of hazards, risks and threats from the occurrence of the effects of explosive material explosions in the Serbian Army are applied in order to increase the level of protection of people's lives and health, material goods and the environment. 
In order to prove the hypothesis using the research results, a survey ${ }^{10}$ was conducted online (https://docs.google.com/forms/d/1bGmu-PnrT4Y gOIIBiNOQ34jcGOcWWa8ahwiyLuDxsfl/viewform?usp=sendform). The aim of the survey was to assess to which extent each method for the mitigation of the effects of the explosive material explosions was really present in the workplaces of the Serbian Army members and during the training of the Military Academy cadets. The survey was based on the information gathered on the views and opinions of the respondents. From the survey results (Figures 2-8) it can clearly be seen that out of 117 surveyed members of the Serbian Army, at the moment of the decision-making, a high percentage of them decided to mitigate a hazard, risk and threat from the explosion of explosive materials in one of the proposed ways.

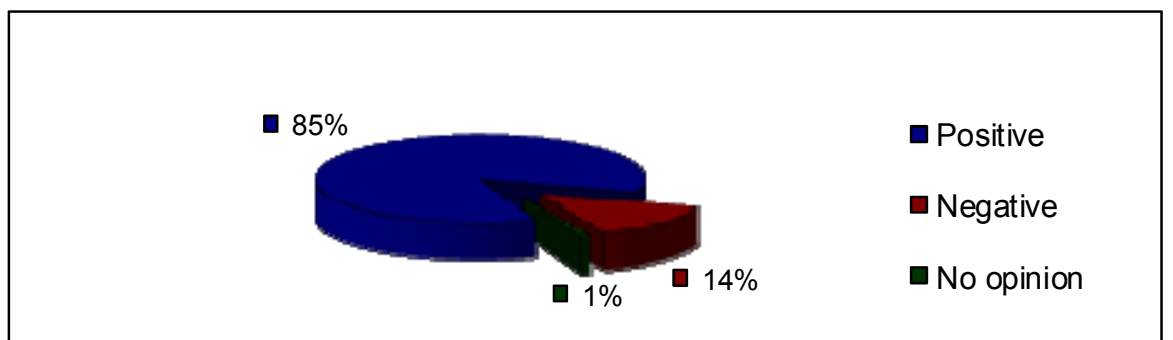

Figure 2 - Assessment of the avoidance of an activityfor which it is estimated to be able to lead to explosion of explosive materials

Puc. 2 - Оценка прекращениядеятельности, которая может привести к взрыву взрывчатых средств

Slika 2 - Ocena izbegavanja realizacije aktivnosti za koju se proceni da može dovesti do pojave eksplozije eksplozivnih sredstava

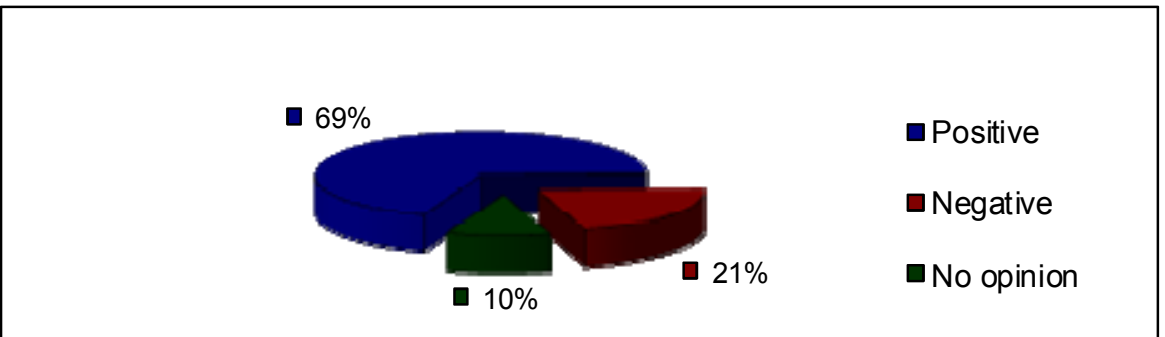

Figure 3 - Assessment of the mitigation of hazards, risks and threats from the effects of the explosion of explosive materials in a subconscious manner

Puc. 3 - Оценка смягчения опасности, рисков и угроз от взрыва взрывчатых средств, на подсознательном уровне

Slika 3 - Ocena ublažavanja opasnosti, rizika i pretnji od pojave efekata eksplozije eksplozivnih sredstava na podsvestan način

${ }^{10}$ From a large number of different definitions of the survey, the most acceptable is the Moser's definition: "The survey is a technical procedure for gathering factual material by combiningstatistical sampling with the method of interviews or questionnaires" (Mozer, 1962, p.5). 


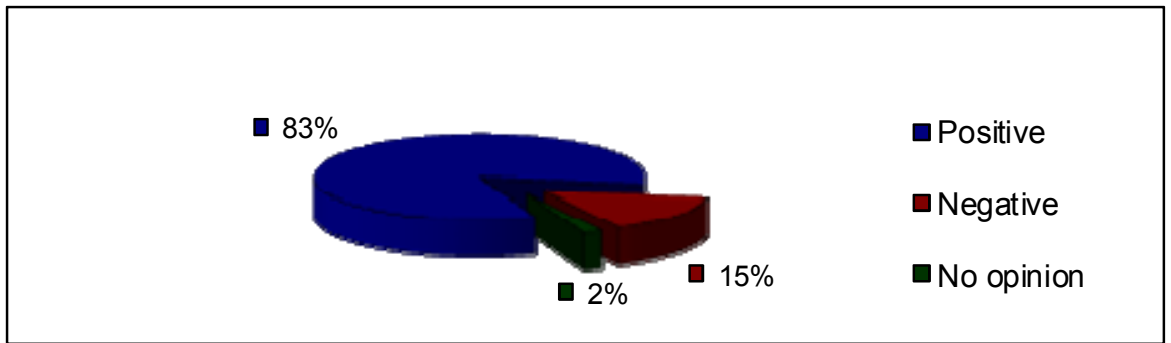

Figure 4 - Assessment of the mitigation of hazards, risks and threats from the effects of the explosion of explosive materials in a conscious manner

Puc. 4 - Оценка смягчения опасности, рисков и угроз от взрыва взрывчатых средств, на сознательном уровне

Slika 4 - Ocena ublažavanja opasnosti, rizika i pretnji od eksplozije eksplozivnih sredstava na svestan način

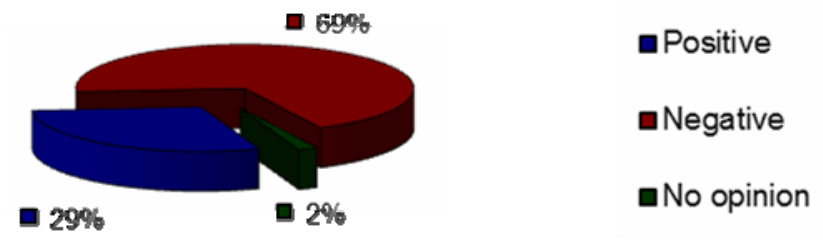

Figure 5-Assessment of the transfer of hazards, risks and threats from the explosion of explosive materials to another party

Puc. 5 - Оценка переноса опасности, рисков и угроз от взрыва взрывчатых средствк третьим лицам

Slika 5 - Ocena prenošenja opasnosti, rizika i pretnji od eksplozije eksplozivnih sredstava na drugo lice

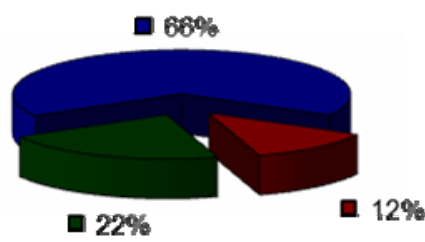

- Positive

-Negative

No opinion

Figure 6 - Assessment of the division of hazards, risks and threats from the explosion of explosive materials into more smaller ones

Puc. 6 - Оценка разложения опасности, рисков и угроз от взрыва взрывчатых средств на составляющие

Slika 6 - Ocena raščlanjivanja opasnosti, rizika i pretnji od eksplozija eksplozivnih sredstava na više parcijalnih 


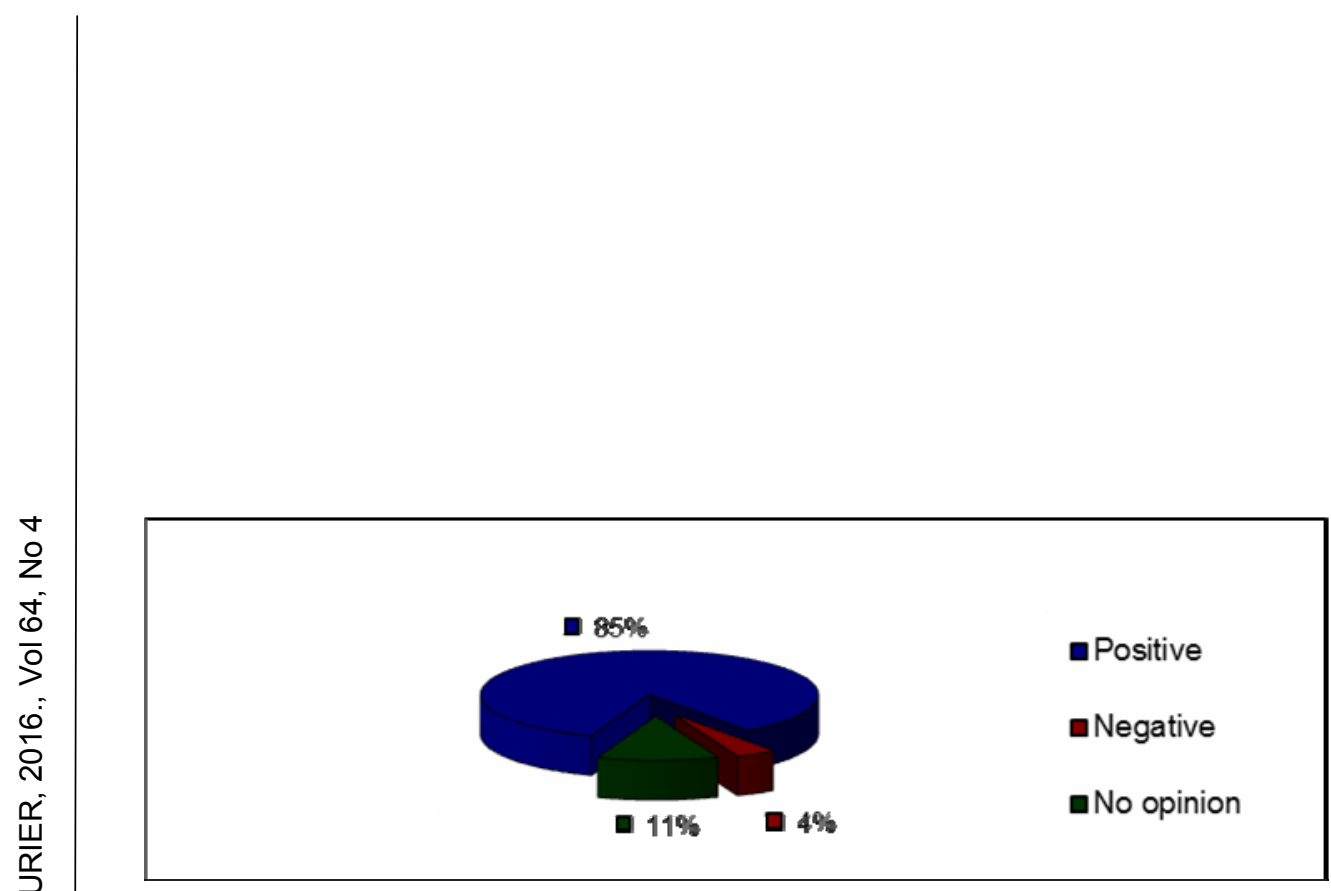

Figure 7 - Assessment of the termination of the work with explosive materials when the body fatigue is felt

Puc. 7 - Оценка прекращения работы с взрывчатыми средствами, при выявлении слабости в организме

Slika 7 - Ocena prestanka rada sa eksplozivnim sredstvima kada se primeti slabost organizma

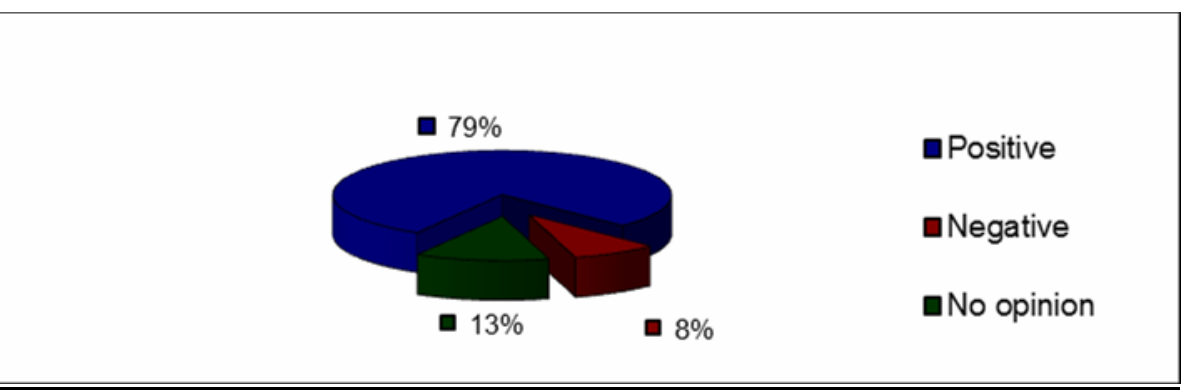

Figure 8 - Assessment of the reduction of hazards, risks and threats from explosive materials by implementing regulative provisions

Puc. 8 - Оценка снижения опасности, рисков и угроз от взрыва взрывчатых средств, в соответствии с регламентом

Slika 8 - Ocena smanjenja opasnosti, rizika i pretnji od eksplozivnih sredstava primenom pravilskih odredbi

A smaller number of the Serbian Army members, however, would not decide to mitigate the hazards, risks and threats from the explosion of explosive materials in any of the proposed ways. It is also important to note that a higher percentage of the Serbian Army members would not transfer the hazards, risks and threats to another person at a decisionmaking moment. They would complete the task on their own responsibility despite the awareness of the fact that they could bear certain consequences in case of making a wrong decision. Based on the views and opinions of the respondents to the survey, the set hypothesis is partially proven because the proposed measures for mitigation of hazards, risks and threats from the effects of explosive material explosionsat the decision-making moment are not applied at the requested level. 
In order to reduce uncertainty in making timely and appropriate decisions in situations where there is danger, risk and threat from the effects of explosive material explosions, it has been suggested that this area be included in the training of Serbian Army members and cadets of the Military Academy. These research results could have applications in monitoring and training of the staff of the Serbian Army to make rational decisions in preventive activitiesin order to eliminate the consequences of any explosion of explosive materials. Lectures based on scientific knowledge would bea part of crisis management adapted to the curriculum at the Military Academy so that the members of the Serbian Army would be ready to respond to changes and challenges, which requires a constant ability to improve the process of mitigating safety vulnerability of people and property from the effects of the explosion of explosive materials in order to ensure optimal protection of the environment and increase the safety of people and property.

A detailed program for the mitigation of the safety risk to people and property from the effects of the explosion of explosive materials is a result of considering all alternative methods studied in the paper, dealing with the prevention from exposure to hazards, risks and threats of the effects of explosive material explosions. A collaborative use of these methods is a special contribution of this work to the community, especially to the members of the Serbian Army who are exposed to hazards, risks and threats of the effects of explosive material explosionson a daily basis. The methods discussed in this work should help employees who work with explosives or are in their immediate vicinity to rationally make the right decision based on their abilities and functions they perform. Unfortunately, practice has shown that not all decisions were appropriate in specific situations; hence invalids and those who got killed during cluster bombs clearing because they did not make the right decision in the given moment of decision-making. If they had applied the proposed methods for avoiding, retention, impairment, division, transfer and reduction of hazards, risks and threats there would have been fewer casualties and less property damage.

This problem has beenin the center of attention for the last couple of years when the effects of explosions of explosive materials were frequent, which indicates a high probability that they will occur in the future. Therefore, the results of this research should be applied in practice. Currently, this issue is not sufficiently considered for several reasons (such as ignorance, insecurity, lack of understanding, etc.) until the highest level of command in the Serbian Army takes greater care and responsibility for protecting people, material resources and the environment. 


\section{Conclusion}

Members of the Serbian Army improve their abilities for the purpose of optimal defence of their physical and mental integrity, as a function of preserving the independence, territorial integrity and sovereignty of the country and its protection from external armed threats. During this complex process, they face many dangers, risks and threats of possible occurrences of the effects of explosive material explosions and mitigate them by making right decisions the results of which maintain the necessary safety. However, they sometimes fail to provide complete safety because at critical moments they consciously expose themselves to dangers, risks and threats, regardless of the possible outcome, which is why in the last few years some events with the disastrous outcome have occurred. For these reasons, members of the Serbian Army should enhance their knowledge in mitigating safety vulnerability, in order to bring danger, risk and the threat from explosions of explosive materials to the lowest possible level of appearance.

Based on the conducted survey on the views and opinions of a representative sample, it was found that the proposed methods to mitigate hazards, risks and threats of the effects of explosive material explosions are not sufficiently represented in the Serbian Army. Therefore, a solution has been proposed in order to increase the level of their implementation through acquiring relevant knowledge during the training of the Serbian Army members for the purpose of improving constructive reasoning, decision making and taking appropriate actions. The purpose of this would be to increase the safety of people and the property. Taking concrete actions to eliminate hazards, risks and threats from the appearance of the effects of explosions of explosive materials represents the future direction of activities of the Serbian Army in order to prevent negative consequences for particular areas in which explosive materials are located or in which they could be found. This matter will be dealt with in one of the next editions of the Military Technical Courier.

\section{References}

Centar za razminiranje / Mine Action Centre, [Internet], Retrieved from: http://www.czrs.gov.rs/lat/o-nama.php, 23. 10. 2015.

Karović, S., Komazec, N., 2010, Upravljanje rizikom na sistematskim osnovama, Vojno delo, Beograd, 62(2), pp.228-240.

Keković, Z., Nikolić, V., 2006, Proces integralnog upravljanja rizicima u organizacijama, Bezbednost, 48(3), pp.414-424.

Mijalkovski, M., Đorđević, I., 2010, Rizik - specifičan oblik ugrožavanja bezbednosti, Vojno delo, 62(1), pp.282-306.

Mozer, C. A., 1962, Metodi anketiranja u istraživanju društvenih pojava, Kultura, Beograd.

Pravilo službe Vojske Srbije / Service Regulations of the Serbian Armed Forces, 2008, Beograd. 
Radovanović, R., 2011, Bezbednosna zaštita lica i imovine, prezentacija, Beograd, Kriminalističko - policijska akademija.

Research hypothesis [Internet], Retrieved from:

http://www.ef.uns.ac.rs/Download/metodologija_nir/12\%20hipoteza\%20istrazivanja.pdf., 02. 11. 2014.

Službeni vojni list / Official Military Gazette, 2015, Pravilnik o zaštiti od požara u ministarstvu odbrane i Vojsci Srbije, Beograd.

Stojanović, D., 2015, Procena bezbednosne ugroženosti ljudi i imovine od efekata eksplozije eksplozivnih sredstava u Vojsci Srbije / Assessment of the security risk to people and property from ordnance explosion effects in the Serbian Armed Forces, Vojnotehnički glasnik/Military Technical Courier, 63(4), pp.135-165.

Upustvo za rad skladišta ubojnih sredstava / Manual for ordnance warehouses, 2002, Generalštab Vojske Jugoslavije, Beograd.

Vujović R., 2009, Upravljanje rizicima i osiguranje, Univiezitet Singidunum, Beograd.

СМЯГЧЕНИЕ УГРОЗЫ БЕЗОПАСНОСТИ НАСЕЛЕНИЯ И ИМУЩЕСТВА ОТ ПОСЛЕДСТВИЙ ВЗРЫВА ВЗРЫВЧАТЫХ СРЕДСТВ В ВООРУЖЕННЫХ СИЛАХ РЕСПУБЛИКИ СЕРБИЯ

Деян С. Стоянович ${ }^{a}$, Петар Л. Стоилькович ${ }^{6}$

аооруженные силы РС, 4-ая пихотная бригада, г. Вранье,

Республика Сербия

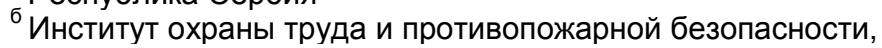
ООО «ВИП Центр» г. Лесковац, Республика Сербия

ОБЛАСТЬ: охрана окружающей среды и критический менеджмент ВИД СТАТЬИ: обзорная статья

ЯЗЫК СТАТЬИ: английский

Резюме:

На основании данного исследования представлены возможности смягчения угрозы безопасности населения и имущества от взрыва взрывчатых средств. Исследование проведено с целью определения мер по снижению опасности, рисков и угроз длянаселения, имущества и окружающей среды и смягчения последствий чрезвычайных ситуаций. B cmamье также подробно описаны следующие методы: профрилактика, отсрочивание, снижение, распределение, перенос и уменьшение опасности, рисков и угроз, подкрепленные соответствующими практическими примерами. В процессе исследования, автор стремился доказать гипотезу с объективностью научного подхода к результатам собственных трудово применении представленных методов.

Ключевые слова: опасность, угроза, войска, имущество, взрывчатые вещества. 


\title{
UBLAŽAVANjE BEZBEDNOSNE UGROŽENOSTI LjUDI I IMOVINE OD EFEKATA EKSPLOZIJE EKSPLOZIVNIH SREDSTAVA U VOJSCI SRBIJE
}

\author{
Dejan S. Stojanovića ${ }^{a}$ Petar Lj. Stojilković ${ }^{b}$ \\ ${ }^{a}$ Vojska Srbije, 4. brigada KoV, Vranje, Republika Srbija \\ ${ }^{\mathrm{b}}$ Institut za bezbednost i zdravlje na radu i zaštitu od požara VIP Centar \\ d.o.o. Leskovac, Republika Srbija \\ OBLAST: zaštita životne sredine i krizni menadžment \\ VRSTAČLANKA: pregledni članak \\ JEZIKČLANKA: engleski
}

\section{Sažetak:}

Istraživanjem su obuhvaćene mogućnosti za ublažavanje bezbednosne ugroženosti ljudi $i$ imovine od efekata eksplozije eksplozivnih sredstava koje imaju za cilj da smanje opasnost, rizik i pretnju po stanovništvo, njihovu imovinu i životnu sredinu, kao i da ublaže posledice moguće vanredne situacije. Razmotrene su sledeće metode: izbegavanje, zadržavanje, umanjenje, podela, prenos i redukcija opasnosti, rizika i pretnji. Svaka metoda je detaljno teorijski objašnjena, uz adekvatne primere iz prakse. Dokazivana je postavljena hipoteza koja ima za cilj da, prilazeći s naučnom objektivnošću vlastitim rezultatima istraživanja, prihvati ili odbaci predložene metode.

Ključne reči: pretnja, opasnost, vojska, imovina, eksploziv.

Paper received on / Дата получения работы / Datum prijema članka: 02. 06. 2015. Manuscript corrections submitted on / Дата получения исправленной версии работы / Datum dostavljanja ispravki rukopisa: 28. 04. 2016.

Paper accepted for publishing on / Дата окончательного согласования работы / Datum konačnog prihvatanja članka za objavljivanje: 30. 04. 2016.

(C) 2016 The Authors. Published by Vojnotehnički glasnik / Military Technical Courier (www.vtg.mod. gov.rs, втг.мо.упр.срб). This article is an open access article distributed under the terms and conditions of the Creative Commons Attribution license (http://creativecommons.org/licenses/by/3.0/rs/).

() 2016 Авторы. Опубликовано в "Военно-технический вестник / Vojnotehnički glasnik / Military Technical Courier" (www.vtg.mod.gov.rs, втг.мо.упр.срб). Данная статья в открытом доступе и распространяется в соответствии с лицензией "CreativeCommons" (http://creativecommons.org/licenses/by/3.0/rs/).

(C) 2016 Autori. Objavio Vojnotehnički glasnik / Military Technical Courier (www.vtg.mod.gov rs, втг.мо.упр.срб). Ovo je članak otvorenog pristupa i distribuira se u skladu sa Creative Commons licencom (http://creativecommons.org/licenses/by/3.0/rs/).

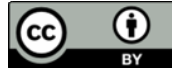

